\title{
Hydrocarbon degradation by bacteria from rhizospheres of Imperata cylindrica at oil mining site in Wonocolo, Bojonegoro, Indonesia
}

\author{
MUTIARA ARUM SARI ${ }^{1}$, ENDAH RETNANINGRUM ${ }^{2, \boldsymbol{v}}$ \\ ${ }^{1}$ Graduated Program in Biology, Faculty of Biology, Universitas Gadjah Mada. Jl. Teknika Selatan, Sekip Utara, Sleman 55281, Yogyakarta, Indonesia \\ ${ }^{2}$ Microbiology Laboratory, Faculty of Biology, Universitas Gadjah Mada. Jl. Teknika Selatan, Sekip Utara, Sleman 55281, Yogyakarta, Indonesia. \\ Tel./fax: +62-274-580839, ^email: endahr@ugm.ac.id
}

Manuscript received: 30 May 2019. Revision accepted: 30 November 2019.

\begin{abstract}
Sari MA, Retnaningrum E. 2019. Hydrocarbon degradation by bacteria from rhizospheres of Imperata cylindrica at oil mining site in Wonocolo, Bojonegoro, Indonesia. Biodiversitas 20: 3422-3429. High oil mining activities cause environmental pollution at the oil mining site. Petroleum spills and waste to the river flow cause blackish discoloration along the riverbank and also some types of plants die. The utilization of rhizospheric bacteria (rhizobacteria) as a bioremediation agent is considered as appropriate for reducing petroleum contaminants. The purposes of this study were to analyze the ability of hydrocarbon degradation by selected rhizobacteria isolates, to identify molecularly and analyze the genetic relationship of hydrocarbon-degrading rhizobacteria based on 16S rRNA gene sequencing. The rhizobacteria of cogongrass (Imperata cylindrica L.) were isolated from oil mining site in Wonocolo, Kedewan, Bojonegoro, East Java, Indonesia. The 5 isolates of rhizobacteria were then cultured on Bushnell-Haas Mineral Salt (BHMS) medium with the addition of $0.015 \%$ crude oil for analyzing their growth based on their cell densities using the Total Plate Count method. The optimal rhizobacteria growth obtained (MTMW2 isolate) was selected and further analysed its ability for hydrocarbon degradation through measuring of Total Petroleum Hydrocarbon (TPH). Its rhizobacteria were then identified using 16S rRNA gene sequencing. The MTMW2 isolate revealed specific growth rate of 0.14 in BHMS medium with the addition of $0.015 \%$ crude oil. After 10 days of incubation, the isolates could degrade Total Petroleum Hydrocarbon in the medium as much as 96.1\%. The results of molecular identification and phylogenetic tree construction showed that MTMW2 isolate was identified as Pseudomonas aeruginosa.
\end{abstract}

Keywords: 16S rRNA gene, hydrocarbons biodegradation, phylogenetic tree, Pseudomonas aeruginosa, rhizobacteria

\section{INTRODUCTION}

Indonesia is one of the world's oil producer countries that is able to produce oil up to 801.4 thousand barrels per day in 2017. Petroleum is a dark, sticky and viscous liquid which is composed of complex compound of hydrocarbons and non-hydrocarbons (Vieira et al. 2007; Han et al. 2018). Organic compounds that dominate the composition of petroleum are aliphatic and aromatic hydrocarbons (Rajaei et al. 2013). Aromatic compounds are one of the most stable and long-lasting petroleum compounds in the environment (Turner and Renegar 2017). Most hydrocarbons are mutagenic and toxic, especially in aromatic hydrocarbon compounds (Joye et al. 2018).

One of oil mining sites in Indonesia that has abundant petroleum resources is located in Wonocolo, Kedewan, Bojonegoro, East Java. High petroleum mining activities cause environmental pollution at the oil mining site. Industrial activity accidents cause petroleum pollution in various environments, such as land surface, groundwater and oceans (Souza et al. 2014). Petroleum spills, and disposal of petroleum waste to the river flow cause blackish discoloration along the riverbank and also some types of plants die. Petroleum pollution not only affects the environment, but also affects the changes in population or community of a species and even has a large impact on the ecosystem (Walker 2006).
Rhizosphere is a land zone which is influenced by plant roots with high bacterial activity, and has complex interaction characteristics both physically, chemically and biologically (Lagos 2015). Rhizospheric bacteria or rhizobacteria are bacteria that live in the rhizosphere which influence the soil properties. Utilization of rhizobacteria as a bioremediation agent is considered an appropriate method for reducing petroleum pollutants. Those petroleum pollutants could be degraded by microorganisms under natural conditions into harmless compounds, such as $\mathrm{CO}_{2}$, $\mathrm{H}_{2} \mathrm{O}$, or other transformation products, and biomass without affecting the environment (Chen et al. 2012; Ron and Rosenberg 2014). Rhizobacteria are able to degrade hydrocarbons because they have an enzyme system and the ability to metabolize hydrocarbon compounds (Rajaei et al. 2013). Rhizobacteria also have a resistance mechanism to survive in contaminated environments (Qian-rui et al. 2006). Even some rhizobacteria secrete biosurfactants to facilitate desorption of organic pollutants, increase bacterial bioavailability, and accelerate degradation of TPH (Lai et al. 2009; Retnaningrum and Wilopo 2018). Some genera of rhizobacteria which have the ability to degrade hydrocarbons, such as genera Acinetobacter, Pseudomonas, Enterobacter, Cronobacter, Stenotrophomonas, Achromobacter, Ochrobactrum, Paenibacillus, Microbacterium, Curtobacterium, Bacillus, and Sphingobacterium (Rajaei et al. 2013; Retnaningrum and Wilopo 2018). 
Although there are a lot of oil mining areas in various provinces in Indonesia, there has not been much research on oil degradation using rhizobacteria. The rhizobacteria used in this research are isolated from rhizospheres of cogongrass (Imperata cylindrica L.) which can survive in unfavorable environments including in the petroleumcontaminated area of oil mining site in Wonocolo, Kedewan, Bojonegoro, East Java, Indonesia. This plant species was declared to tolerate petroleum hydrocarbons (Onyemauche et al. 2018). In addition, the grass plant group has been reported to be appropriate for phytoremediation of petroleum hydrocarbon contaminants (Dudai et al. 2018; Dominguez et al. 2019). As reported by Hameed et al. (2010), cogongrass is a member of the family Poaceae which shows the adaptation of specific root and stem anatomy. This plant species has a fibrous root system which causes an increase in the root surface area and is able to penetrate to a soil depth of $3 \mathrm{~m}$ (RoyChowdhury et al. 2015; Kiiskila et al. 2019). Rhizobacteria can also reduce the toxicity of the pollutants so that plants can grow well (Singh et al. 2012; Abhilash et al. 2013; Truu et al. 2015). Therefore, the aim of this research was to analyze the ability of hydrocarbondegrading rhizobacteria, to identify and analyze the genetic relationship the hydrocarbon-degrading rhizobacteria based on sequencing $16 \mathrm{~S}$ rRNA gene. Due to the high potency to degrade hydrocarbons by the rhizobacteria, its isolate is becoming a cheap and environmentally friendly bioremediation agent.

\section{MATERIALS AND METHODS}

\section{Sampling and analysis of soil samples}

Rhizosphere soil was collected from the cogongrass (Imperata cylindrica L.) present at the contaminated soil in Wonocolo, Kedewan, Bojonegoro, East Java, Indonesia. The plants were pulled and shaken to loose the bulk soil attached to the roots, and then soil was collected as much as about 1 gram. The soil samples were sifted with a $2 \mathrm{~mm}$ mesh. Furthermore, these samples were analyzed to obtain $\mathrm{pH}$ and Total Petroleum Hydrocarbon (TPH) values.

\section{Isolation of rhizobacteria isolates}

One gram of soil sample was added to the BushnellHaas Mineral Salt (BHMS) medium. The composition of BHMS medium per liter was consist of $0.2 \mathrm{~g} \mathrm{MgSO}_{4} .7 \mathrm{H}_{2} \mathrm{O}$, $0.02 \mathrm{~g} \mathrm{CaCl}_{2}, 1.0 \mathrm{~g} \mathrm{KH}_{2} \mathrm{PO}_{4} ; 1.0 \mathrm{~g} \mathrm{~K}_{2} \mathrm{HPO}_{4}, 1.0 \mathrm{~g} \mathrm{NH}_{4} \mathrm{NO}_{3}$, $0.005 \mathrm{~g} \mathrm{FeCl}_{3}$, supplemented with $0.015 \%$ crude oil and tween 80 . Rhizobacteria cultures were then incubated for 21 days at $30^{\circ} \mathrm{C}$ with 3 times of subcultures. Third subculture was further inoculated into the BHMS agar medium and incubated for 2 days at $30^{\circ} \mathrm{C}$. Growing bacterial colonies were selected according to their differences in colony and cell morphological features. The selected colonies of rhizobacteria isolates were then inoculated to the new BHMS agar medium to obtain pure isolates

\section{Measuring rhizobacteria growth on crude oil $0.015 \%$}

Strains were observed for their ability to utilize hydrocarbon content in crude oil as sole carbon source by culturing them on Erlenmeyer containing BHMS added with $0.015 \%(\mathrm{v} / \mathrm{v})$ of crude oil. The cultures were incubated for 120 hours at $30^{\circ} \mathrm{C}$. At interval of 12 hours, the cultures were analyzing their growth using the Total Plate Count (TPC) method. Each specific growth rate of rhizobacteria isolates was measured using the following equation (Maier and Pepper 2009):

$$
\mu=0.693 \times \frac{\log N t-\log N 0}{0.301 \times t}
$$

Where:

$\mathrm{k} \quad$ : the constant of growth rate (generation/second)

N0 : the initial number of bacteria during the exponential phase $(\mathrm{CFU} / \mathrm{mL})$

$\mathrm{N}$ : the number of bacteria after growing during $\mathrm{t}-$ time $(\mathrm{CFU} / \mathrm{mL})$

$\mathrm{t}:$ : the growth time at exponential phase (second)

$\mu \quad$ : the specific growth rate

\section{Analysis of Total Petroleum Hydrocarbons (TPH)}

The bacteria which has the highest specific growth rate was selected and further analyzing on hydrocarbondegrading ability. This degradation ability was observed by growing the isolate on the BHMS liquid medium added $0.015 \%$ of crude oil. After 10 days incubation, Total Petroleum Hydrocarbon (TPH) of culture was performed using a Shimadzu Gas Chromatography-2010 which was equipped with a Flame Ionization Detector (GC-FID) with a RTX-5 column, $30 \mathrm{~m}$ long (Srivastva et al. 2017)

\section{Identification and phylogenetic analysis of} rhizobacterial isolates using $16 \mathrm{~S}$ rRNA gene sequencing

Morphological analyses followed by $16 \mathrm{~S}$ rRNA gene sequencing were conducted for identification of the isolate. These morphological characters were carried out by observing their cell shape, gram staining and colony properties (color, shape, elevation, margin and inner structure).

The isolation of DNA from rhizosphere bacteria isolates was carried out using the Quick-DNA ${ }^{\mathrm{TM}}$ Fungal/Bacterial Miniprep (Zymo Research). Previously a $35 \mathrm{~mL}$ overnight grown bacterial isolate prepared and maintained in Nutrient Broth (NB). This culture was transferred into the falcon tube and centrifuged $4000 \mathrm{rpm}$ for 20 minutes. Collected pellets were resuspended with $1 \mathrm{~mL}$ of $\mathrm{ddH}_{2} \mathrm{O}$. Pellets were transferred to the 1.5 microtubes and then centrifuged of $10,000 \mathrm{rcf}$ for 10 minutes. Pellets were separated and collected in enough quantity cells in the range of 50-100 $\mathrm{mg}$, then resuspended with $1 \mathrm{~mL} \mathrm{ddH}_{2} \mathrm{O}$. This suspension was transferred to the ZR BashingBeads lysis tube and added with $600 \mu \mathrm{L}$ of cogongrass. The pellets were vortexed at low speed for 25 minutes. The ZR lysis tube was centrifuged 10,000 rcf for 1 minute. As much as $400 \mu \mathrm{l}$ supernatant was transferred to the ZymoSpin IIIF filter tube and collection tube. The supernatant was centrifuged for 1 minute at 10,000 $\mathrm{rcf}$. The resulting filtrate was resuspended 
after adding $1000 \mu \mathrm{L}$ genomic lysis buffer. About $800 \mu \mathrm{L}$ of filtrate was transferred to the ZymoSpin IIC filter tube with a new collection tube. The filtrate was centrifuged $10,000 \mathrm{rcf}$ for 1 minute. The filtrate in the ZymoSpin IIC filter tube was added with $200 \mu \mathrm{L}$ of pre-washed DNA buffer and the collection tube was replaced with a new one. The filtrate was centrifuged again $10,000 \mathrm{rcf}$ for 1 minute. About $400 \mu \mathrm{L}$ gDNA washed buffer was added to the ZymoSpin IIC filter tube and then centrifuged 10,000 rcf for 1 minute. The collection tube was replaced with $1.5 \mathrm{~mL}$ microtube and added with $50 \mu \mathrm{L}$ of elution buffer DNA. The filtrate was centrifuged again for 1 minute at 10,000 rcf. DNA extract is stored in a freezer at $-20^{\circ} \mathrm{C}$ temperature. The presence of bacterial DNA isolates was analyzed by electrophoresis technique. The purity of bacterial DNA isolates was analyzed using UV-Vis NanodropSpectrophotometer (Thermo Scientific) at A260/A280 wavelengths.

Amplification of bacterial DNA isolates was carried out using GoTaq ${ }^{\circledR}$ Green Master Mix with the forward primers 27F (5'- AGAGTTTGATCMTGGCTCAG -3') and the reverse primer 1492R TACGGYTACCTTGTTACGACTT -3') (Rajaei et al 2013). The PCR mixture composition: such as $12.5 \mu \mathrm{L}$ GoTaq ${ }^{\circledR}$ Green Master Mix 2X (1x final concentration), 1 $\mu \mathrm{L}$ Forward primer $(0.2 \mu \mathrm{M}), 1 \mu \mathrm{L}$ Reverse primer $(0.2$ $\mu \mathrm{M}), 1 \mu \mathrm{L}$ DNA template $(<250 \mathrm{ng}), 9.5 \mu \mathrm{L}$ of NucleaseFree Water (NFW) with a total amount should be $25 \mu \mathrm{L}$. Amplification of 16S rRNA gene was performed using Thermo Cycler (BIORAD) PCR. After PCR cocktail ready, PCR cocktail was inserted to the PCR machine. The amplification reaction was carried out in 30 cycles consisting of several stages, such as the predenaturation stage at $95^{\circ} \mathrm{C}$ for 3 minutes, the denaturation stage at $95^{\circ} \mathrm{C}$ for 30 seconds, the annealing stage at $57^{\circ} \mathrm{C}$ for 1 minute, the extension stage at $72^{\circ} \mathrm{C}$ for 1 minute 40 seconds and the final extension stage at $72^{\circ} \mathrm{C}$ for 1 minute 40 seconds. Amplicon was detected by electrophoresis system (MupidexU) with the $1 \%$ agarose gel concentration (w/v) then visualized with UV Transluminator using ZR $1 \mathrm{~kb}$ DNA Marker.

The amplicon of 16S rRNA gene was sequenced and its sequences were compared with other $16 \mathrm{~S}$ rRNA genes based on the database in GenBank through the BLAST tools on the www.ncbi.nlm.nih.gov. The results of $16 \mathrm{~S}$ rRNA data sequence alignment then used to construct the phylogenetic tree. The phylogenetic tree was constructed using the Neighbor-Joining (NJ) method by MEGA7 software.

\section{Data analysis}

All experiments were performed in triplicate and the results were expressed as mean values which analyzed using Microsoft Excel 2013. The differences between the means of the tested parameters were statistically analyzed by the t-test and ANOVA $(\alpha=0.05)$ using the statistical package for social sciences (SPSS), version 12.

\section{RESULTS AND DISCUSSION}

\section{Rhizosphere soil sample}

The results of $\mathrm{pH}$ and TPH measurements of rhizosphere soil samples showed that the value of $\mathrm{pH}$ and TPH rhizosphere soil were 8.87 and $0.015 \%$, respectively. Rhizosphere soil samples were isolated in the middle of the dry season, hence the river water receded and the soil conditions turned out dry that induced the soil $\mathrm{pH}$ to be more alkaline. Therefore, alkaline soils tend to have higher levels of microbial diversity compare to acidic soils (Rousk et al. 2010). In that alkaline condition, it was very possible to find bacterial phylum classified as Actinobacteria and Proteobacteria (Khan et al. 2018). The TPH concentration of samples showed that rhizosphere soil was contaminated by petroleum which contained hydrocarbons. Even though the rhizosphere soil was contaminated with hydrocarbons, cogongrass could grow well. It was indicated the presence of microorganisms, especially rhizobacteria in that soil system which could reduce the toxicity of contaminants to a level where plants can grow well. Those rhizobacteria might have ability to degrade hydrocarbon pollutants. Due to that ability, rhizobacteria were able to survive in the contaminated soils through resistance mechanism or an adaption mechanism by doing genetic mutations (McDonald et al. 2006; Qian-rui et al. 2006).

\section{The hydrocarbons-degrading rhizobacteria}

Enrichment for 21 days in BHMS containing $0.015 \%$ crude oil resulted of 5 isolates (MTMW1, MTMW2, MTMW3, MTMW4 and MTMW5). Applying 0.015\% oil in the medium was performed to illustrate the actual condition of the amount of pollutants in the system. In addition, the carbon source for rhizobacteria culture was given only from crude oil. Therefore to optimize the growth of culture, surfactant compound as Tween 80 was added in the medium for increasing the solubility of oil in culture. Its compound would induce the oil adhesion to microbial cell surfaces, resulting in that crude oil degradation (Singh et al. 2007; Tian et al. 2016; Retnaningrum and Wilopo 2018).

\section{The selection of rhizobacteria growth}

The five isolates were screened for further study on the basis of their ability to grow in BHMS containing 0.015\% for 120 hours. For comparing the growth of the rhizobacteria strains, the bacterial numbers were considered using the Total Plate Count (TPC) method. During the incubation, all isolates showed a similar pattern of bacterial growth which includes several phases, such as the lag, the exponential, the stationary and the death phase as displayed in Figure 1.

After 12 hours of incubation, the rhizobacteria isolates reached their lag phase with the cell number variations. The cell number of MTMW1, MTMW3, MTMW4 and MTMW5 isolate were $1.69 \times 10^{7}, 1.29 \times 10^{7}, 1.06 \times 10^{7}$, and $5.3 \times 10^{7} \mathrm{CFU} / \mathrm{mL}$, respectively. On the contrary, MTMW2 isolate did not show an increase in its cell number in that lag phase. During the lag phase, several processes occurred, including synthesis of mRNA and 
protein which were required in adaptation to the new environment (Maier and Pepper 2009).

The rhizobacteria isolates then entered the exponential phase after 24 hours of incubation. This exponential phase showed the highest cell growth compared to other phases. From observations, the cell number of MTMW1, MTMW2, MTMW3, MTMW4 and MTMW5 isolate were $2.6 \times 10^{7}$, $26.9 \times 10^{7}, 2.12 \times 10^{7}, 3.09 \times 10^{7}$ and $2.59 \times 10^{7} \mathrm{CFU} / \mathrm{mL}$, respectively. During that phase bacteria, isolates used the nutrients available in the medium to carry out an optimal cell division (Pelczar and Chan 2010).

At the end of the exponential phase, then the rhizobacteria cells entered the stationary phase. This phase did not indicate changes in the number of cells. The isolate of MTMW1, MTMW3 and MTMW4 achieved this phase at incubation time of 24 to 120 hours. Isolate of MTMW2 reached that phase at incubation time of 24 to 108 hours, whereas the isolate of MTMW5 did not detect. Finally, rhizobacteria isolates reach a death phase which occurred the high bacterial mortality rates due to depletion of nutrient amounts and increased accumulation of their metabolic waste produced (Cappuccino and Sherman 2002).

Based on rhizobacteria cell number which measured in the exponential phase their growth kinetics could be determined as shown in Table 1. Therefore based on the calculations using the reference formula, their specific growth rate could be analyzed (Maier and Pepper 2009). The MTMW2 isolate showed the highest specific growth rate followed by MTMW5, MTMW4. MTMW1 DAN MTMW3. MTMW2 isolate. This MTMW2 isolate was further analyzed its hydrocarbon degradation and identification.

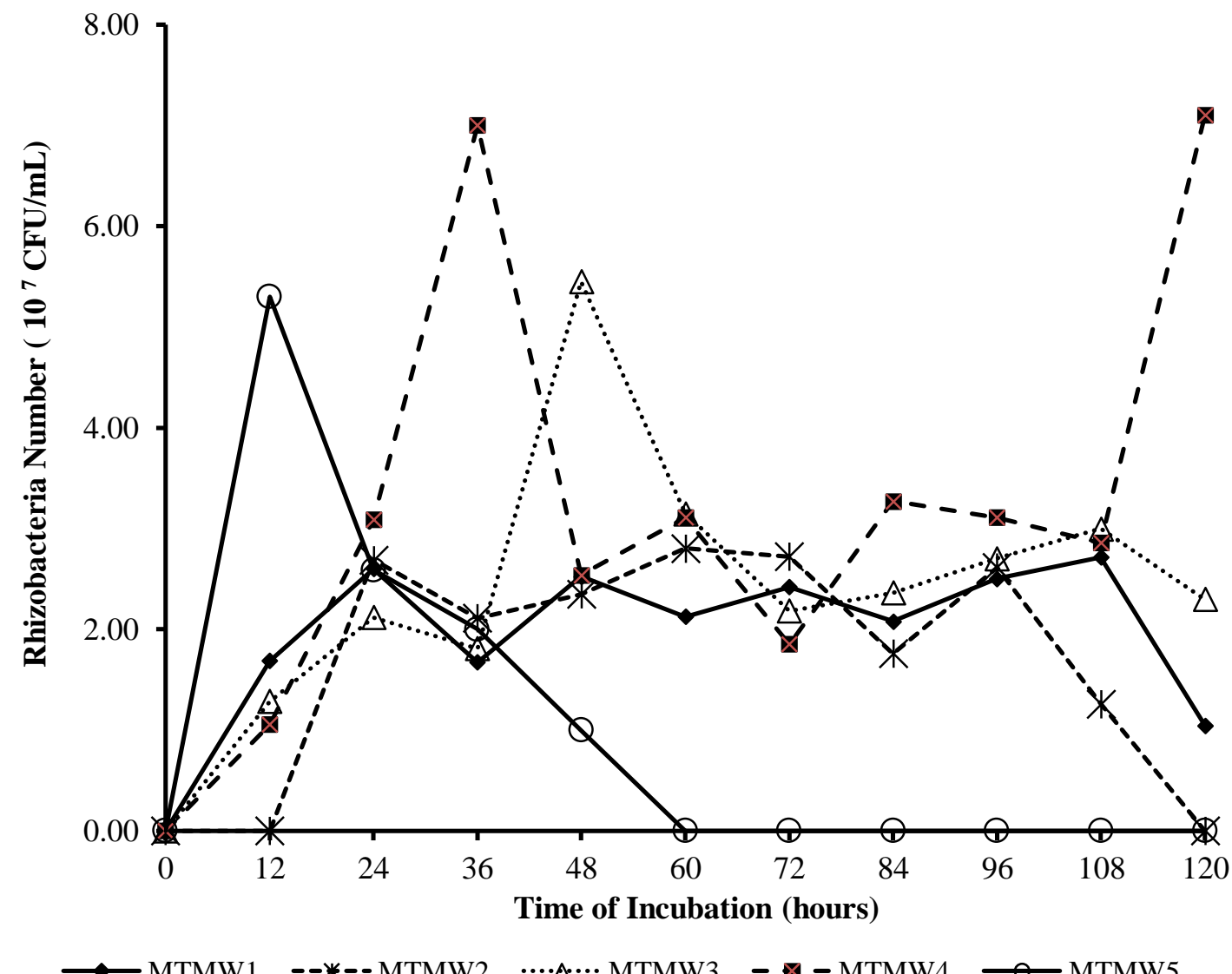

Figure 1. The growth of rizobacteria isolates in BHMS containing $0.015 \%$ crude oil during 120 hours incubation

Table 1. Rhizobacteria isolate growth kinetics

\begin{tabular}{ccccc}
\hline Rhizobacteria isolate & $\begin{array}{c}\text { No } \\
\text { (CFU/mL) }\end{array}$ & $\begin{array}{c}\text { N } \\
\text { (CFU/mL) }\end{array}$ & $\begin{array}{c}\text { K } \\
\text { (Generation/second) }\end{array}$ & $\boldsymbol{\mu}$ \\
\hline MTMW1 & $1.685 \times 107$ & $2.606 \times 107$ & 0.05 & 0.04 \\
MTMW2 & $9.000 \times 106$ & $2.690 \times 107$ & 0.20 & 0.14 \\
MTMW3 & $1.285 \times 107$ & $2.120 \times 107$ & 0.06 & 0.04 \\
MTMW4 & $1.055 \times 107$ & $3.090 \times 107$ & 0.13 & 0.09 \\
MTMW5 & $5.300 \times 106$ & $2.590 \times 107$ & 0.19 & 0.13 \\
\hline
\end{tabular}

Note: $\mathrm{k}$ was the constant of growth rate, N0: the initial number of bacteria during the exponential phase, N: the number of bacteria after growing during $\mathrm{t}$-time, $\mathrm{t}$ : the growth time at exponential phase and $\mu$ : the specific growth rate 
Table 2. The change of TPH and $\mathrm{pH}$ of MTMW2 culture after 10 days incubation

\begin{tabular}{lcc}
\hline \multicolumn{1}{c}{ Measurements } & \multicolumn{2}{c}{ Time incubation (days) } \\
& $\mathbf{0}$ & $\mathbf{1 0}$ \\
\hline Total Petroleum Hydrocarbon (TPH) $(\%)$ & 0.0150 & 0.0006 \\
$\mathrm{pH}$ & 7.82 & 7.51 \\
\hline
\end{tabular}

Table 3. Morphological characters of MTMW2 isolate

\begin{tabular}{lll}
\hline \multicolumn{2}{c}{ Characters } & \multicolumn{1}{c}{ Result } \\
\hline Cell morphology & Shape & Slightly curved rods \\
& Gram stain & Negative (-) \\
Colony morphology & Color & Blue-green \\
& Shape & Irregular \\
& Elevation & Effuse \\
& Margin & Undulate \\
& Inner structure & Smooth \\
\hline
\end{tabular}

\section{Hydrocarbon degradation by selected rhizobacteria isolates}

Observation hydrocarbon degradation by the selected rhizobacteria (MTMW2 isolate) was conducted for 10 days in batch experiment using BHMS added with $0.015 \%$ crude oil and tween 80. After 10 days of incubation, concentration of Total Petroleum Hydrocarbon (TPH) decreased (Table 2). These results showed that MTMW2 isolate had an ability to live and survive in the contaminated environments, as well as its ability to use crude oil as the only $\mathrm{C}$ source for the growth. According to Rajaei et al. (2013), rhizobacteria could degrade hydrocarbons by producing enzymes that contributed in that degradation. In addition, the different types of enzymes were involved in a series of hydrocarbon degradation processes (Abbasian et al. 2015). This degradation processes would produce energy and play a role in cellular synthesis (Leahy and Colwell 1990).

The percentage of petroleum degradation by MTMW2 isolate was quite large about $96.1 \% \quad(\mathrm{p}<0.05)$. This significant reduction of TPH concentration by isolate indicated was influenced by applying of tween 80 in the medium. As reported by Cheng et al. (2017) that the addition of tween 80 induced the decreasing of surface tension. Tween 80 (polyoxyethylene sorbitan monooleate) is a non-ionic surfactant or known as an oil emulsifier in water (Mousset et al. 2014). Surfactants have two groups in one molecule that consist of polar and non-polar groups. One side of the surfactant binds oil which is non-polar and the other side binds to water which is polar, so that the oil is more soluble in water (Farooq et al. 2019). The higher level of oil solubility in water caused easier bacteria to metabolize petroleum.

The $\mathrm{pH}$ measurements also showed a decreasing $\mathrm{pH}$ in those cultures. This decreasing $\mathrm{pH}$ was due to the metabolic product of MTMW2 isolate in the form of organic acids released during the hydrocarbon degradation process. This organic acid production during hydrocarbon degradation was reported by Leahy and Colwell (1990) who investigated the biodegradation of alkanes which were converted into alcohol, alcohol was converted into fatty acids, and fatty acids were oxidized to form acetic acid and propionic acid. Therefore those products altered the $\mathrm{pH}$ of culture to be more acidic.

\section{Morphological characters of MTMW2 isolate}

Morphological analysis result of MTMW2 isolate was shown in Table 3 . Their cells were slightly curved rod-shaped and gram-negative. Based on Bergey's Manual Systematic of Bacteriology which refers to the differentiation of the gram staining and cell morphology character, several bacteria that have rods cell forms and gram-negative possibly included in the genus of Pseudomonas, Bacillus, and Enterobacter (Brenner et al. 2005). In addition their colonies color had blue-green which in accordance with the previous research that investigated that pigment was produced by Pseudomonas aeruginosa. Observations of the shape, elevation, margin and inner colonies of MTMW2 isolates also showed that they were irregular, effuse, undulate and smooth. Therefore this isolate was likely $P$. aeruginosa. To confirm this morphological identification results, the further molecular identification by $16 \mathrm{~S}$ rDNA gene sequencing was conducted.

\section{Molecular identification of MTMW2 isolates by 16S rRNA gene sequencing}

Previously the culture was prepared by incubating its culture in the nutrient broth (NB) medium for 2-3 days for obtaining the large quantities of bacterial cells. Those DNA of cells were then separated and extracted from other cell components by damaging the cell membrane and bacterial cell walls. Those DNA extract concentration measurements showed a value of $108.9 \mathrm{ng} / \mu \mathrm{L}$. This DNA purity was then analyzed using UV-Vis Nanodrop-Spectrophotometer (Thermo Scientific) at A260/A280 wavelengths, resulted in 1.92. As reported by Sambrock et al. (1989), this DNA purity value was still in the range considered pure (1.8-2.0). This DNA extract was then amplification using 16S rRNA gene. As reported by other researchers, this $16 \mathrm{~S}$ rRNA gene can be used as a molecular marker because it is conserved and can be found in all bacteria (Rossi-tamisier et al. 2015; Wang et al. 2015).

The visualization results of PCR products of DNA isolate showed a single band parallels to the marker of $1,500 \mathrm{bp}$ (Figure 2). The presence of thick and bright bands observed indicates that the 16S rRNA target gene was successfully amplified by $27 \mathrm{~F}$ and $1492 \mathrm{R}$ primers. Therefore these amplicons of the 16S rRNA gene can be used for further sequencing analysis.

Sequencing of the 16S rRNA gene is technique that can be used to identify bacteria at the species level and differentiate between bacterial species that still have close relationships (Maiden et al. 1998). The results of the 16S rRNA gene sequencing were compared with other bacterial $16 \mathrm{~S}$ rRNA genes based on the database in GenBank through the Basic Local Alignment Search Tool-Nucleotide (BLASTn) tool on the NCBI website. Based on the BLAST results of 10 bacterial strains with the highest identities value, the MTMW2 isolate showed significant $99.43 \%$ that identity with Pseudomonas aeruginosa (Table 4 ). 


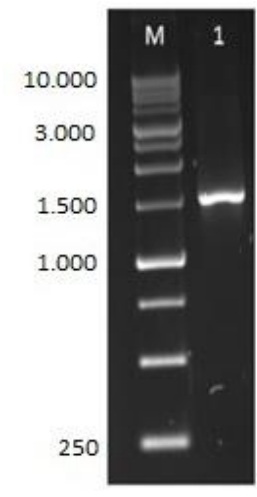

Figure 2. The results of $16 \mathrm{~S}$ rRNA gene amplification using $27 \mathrm{~F}$ and $1492 \mathrm{R}$ primers with $1 \%$ agarose gel electrophoresis. M: 100 bp DNA ladder marker (Geneaid), 1: MTMW2 isolate.

These Identities expressed the percentage of the nucleotide arrangements suitability between the sequences that are held (query) with the sequences in the database (Miller et al. 1990). According to Stackebrandt and Goebel (1994), two strains with the identity values of the $16 \mathrm{~S}$ rRNA gene sequences less than $97 \%$ represent different bacterial species. Therefore, based on that theory, MTMW2 isolate was identified as Pseudomonas aeruginosa. These identities of MTMW2 isolate did not reach $100 \%$ because of the gaps in the nucleotide sequences. The existence of gap indicates the insertion or deletion of one or more characters from a sequence during the evolutionary process (Thompson et al. 1994).

For estimating the relationship of species evolution using gene sequences, phylogenetic analysis is carried out using the Molecular Evolutionary Genetics Analysis (MEGA7) program using the Neighbor-Joining (NJ) method (Choudhuri 2014). The advantages of using Neighbor-Joining (NJ) method are the selection of the sequences that are able to provide the best estimation of the closest branch length so as to reflect the real distance between sequences. This phylogenetic tree construction of MTMW2 isolates used bootstrap 1000 which showed the confidence level in each branch of the phylogenetic tree (Thompson et al. 1994).
Nine closely related bacterial species presented in Table 4 and 3 additional bacterial species including Pseudomonas aeruginosa strains IR-222, Pseudomonas sp. strains of IR211 and Pseudomonas sp. strain of IR-154 were considered as in group of Operational Taxonomic Units (OTUs) in this phylogenetic analysis. Those additional bacterial species were conducted for clarifying the evolutionary relationship in the phylogenetic tree of MTMW2 isolate. In addition, those three bacterial strains have been isolated from the rhizosphere of wild wheat plants (Avena fatua L.) which had the ability to degrade hydrocarbons (Rajaei et al. 2013). Whereas, Rhizobacter profundi was chosen as outgroup of that OTUs selected based on the same ordo with the isolate so that it had a close relationship taxon and thus more significant results will be obtained.

From the phylogenetic tree construction, it was shown that MTMW2 isolate was in the same cluster as Pseudomonas aeruginosa with a $100 \%$ bootstrap value (Figure 3). As reported by Thompson et al. (1994) a phylogenetic tree branch with the bootstrap value $100 \%$ was grouped a very high confidence level. Therefore, the node connecting MTMW2 isolate with Pseudomonas aeruginosa could be acceptable. The phylogenetic tree construction of MTMW2 isolate which identical to Pseudomonas aeruginosa was supported by the BLAST algorithm result. Therefore the MTMW2 isolate was correctly identified as Pseudomonas aeruginosa. In accordance with research conducted by Rajaei et al. (2013), Pseudomonas aeruginosa was also isolated from the rhizosphere of wild wheat plants (Avena fatua L.). This plant species was also classified in the Family of Poaceae which reported had high adaptability in stress environment (RoyChowdhury et al. 2015; Kiiskila et al. 2019).

The alignment results of $16 \mathrm{~S}$ rRNA sequence data were also used to analyze genetic distances. The genetic distance can be obtained using pairwise distance on the MEGA7 program. This genetic distance describes the degree of genetic difference between species that is measured by numerical method. In addition, the strain can be determined as a different species if the genetic distance $<0.15$ (Nei 1987). Based on the calculation, the genetic distance between the MTMW2 isolate and other bacterial isolates were in the range of 0.001-0.209 (Table 5).

Table 4. Identification affiliation of 16S rRNA gene sequences of MTMW2 isolate using the BLAST program

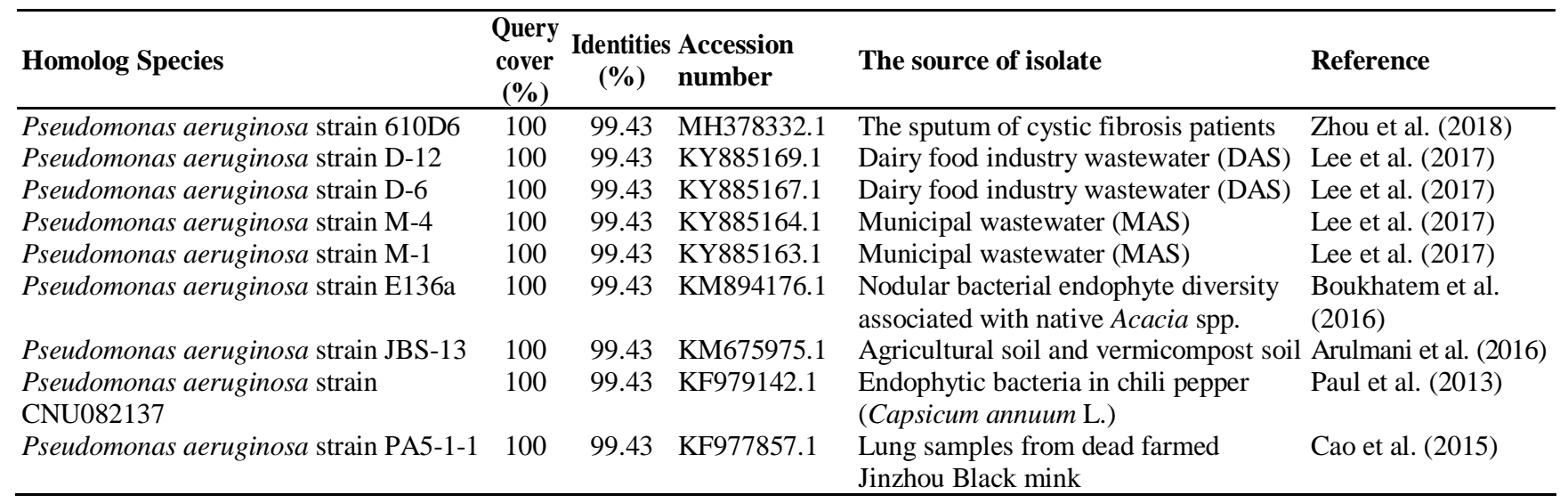




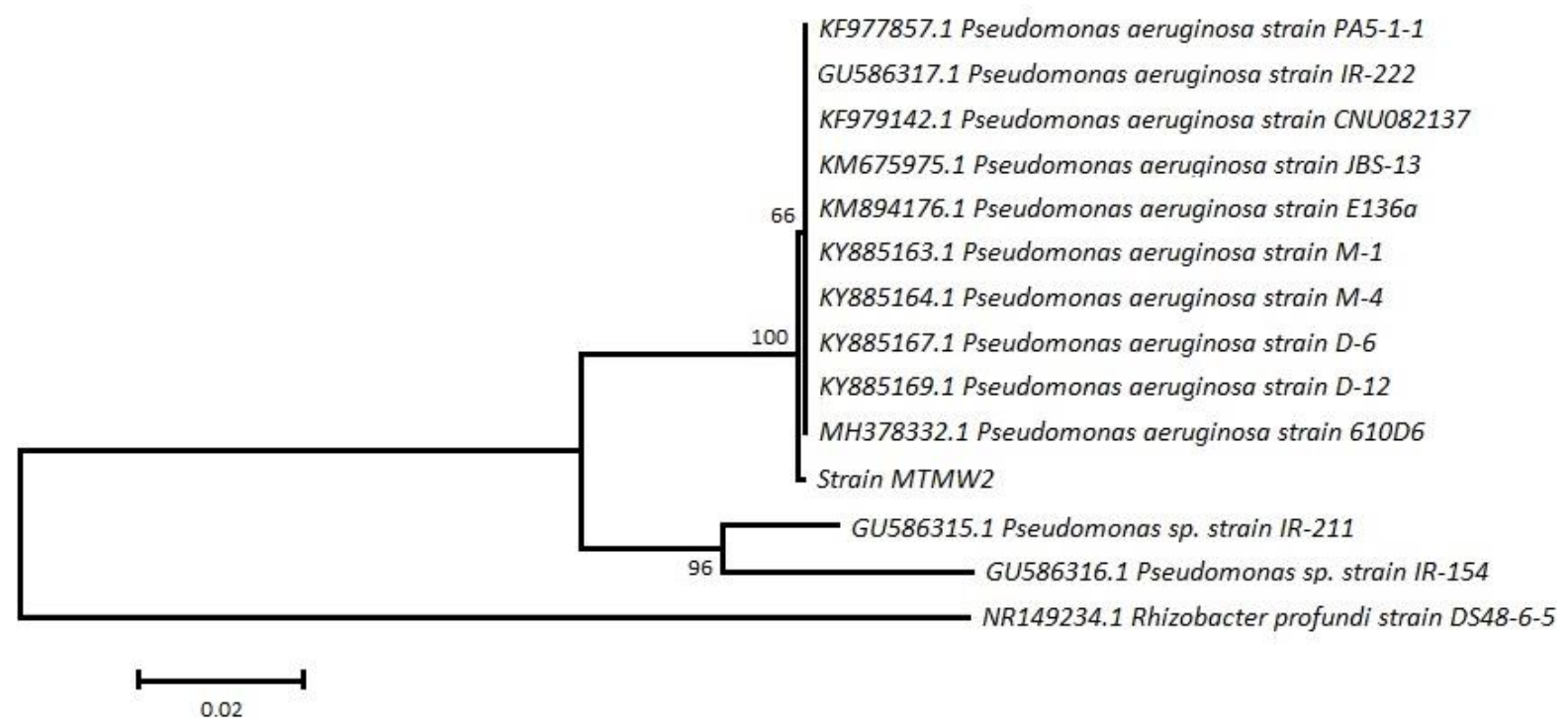

Figure 3. The phylogenetic tree of MTMW2 isolate using the Neighbor-Joining (NJ) method (bootstrap = 1000)

Table 5. Genetic distance between MTMW2 isolate and other bacterial strains

\begin{tabular}{lc}
\hline \multicolumn{1}{c}{ Bacterial strains } & $\begin{array}{c}\text { Genetic } \\
\text { distance }\end{array}$ \\
\hline Pseudomonas aeruginosa strain 610D6 & 0.001 \\
Pseudomonas aeruginosa strain D-12 & 0.001 \\
Pseudomonas aeruginosa strain D-6 & 0.001 \\
Pseudomonas aeruginosa strain M-4 & 0.001 \\
Pseudomonas aeruginosa strain M-1 & 0.001 \\
Pseudomonas aeruginosa strain E136a & 0.001 \\
Pseudomonas aeruginosa strain JBS-13 & 0.001 \\
Pseudomonas aeruginosa strain CNU082137 & 0.001 \\
Pseudomonas aeruginosa strain PA5-1-1 & 0.001 \\
Pseudomonas aeruginosa strain IR-222 & 0.001 \\
Pseudomonas sp. strain IR-211 & 0.059 \\
Pseudomonas sp. strain IR-154 & 0.076 \\
Rhizobacter profundi strain DS48-6-5 & 0.209 \\
\hline
\end{tabular}

The highest value of genetic distance was found between the MTMW2 isolate and Rhizobacter profundi strain DS48-6-5 about 0.209 which indicates that the two strains had a distant relationship, while the lowest value of genetic distance was found among MTMW2 isolate with 10 strains Pseudomonas aeruginosa about 0.001 which indicated that the strain had close relationship. Therefore based on this calculation, MTMW2 isolate was also determined as same species of Pseudomonas aeruginosa.

Based on the investigations, it can be concluded that MTMW2 isolate had an ability to degrade hydrocarbons as much as $96.1 \%$ after 10 days of incubation. In addition, from the alignment, phylogenetic analysis and genetic distance calculation of $16 \mathrm{~S}$ rRNA gene, the isolate was identified and had closely genetic relationship with Pseudomonas aeruginosa. Therefore this isolate was promising as bioagent for hydrocarbon bioremediation.

\section{REFERENCES}

Abbasian F, Lockington R, Mallavarapu M, Naidu R. 2015. A comprehensive review of aliphatic hydrocarbon biodegradation by bacteria. Appl Biochem Biotechnol 176: 670-99.

Abhilash PC, Dubey RK, Tripathi V, Srivastava P, Verma JP, Singh HB. 2013. Remediation and management of POPs-contaminated soils in a warming climate: challenges and perspectives. Environ Sci Pollut Res 20 (8): 5879-5885.

Arulmani SRB, Jayaraj V, Jebakumar SRD. 2016. Long-term electricity production from soil electrogenic bacteria and high-content screening of biofilm formation on the electrodes. J Soils Sediments 16 (3): 831841.

Boukhatem ZF, Merabet C, Bekki A, Sekkour S, Domergue O, Dupponois R, Galiana A. 2016. Nodular bacterial endophyte diversity associated with native Acacia spp. in desert region of Algeria. Afr J Microbiol Res 10 (18): 634-645.

Brenner DJ, Krieg NR, Staley JR. 2005. Bergey's Manual Systematic Bacteriology. Springer, New York.

Cao Z, Zhang J, Niu YD, Cui N, Ma Y, Cao F, Jin L, Li Z, Xu Y. 2015. Isolation and characterization of a "phiKMV-Like" bacteriophage and its therapeutic effect on mink hemorrhagic pneumonia. PLoS ONE 10 (1): e0116571. DOI: 10.1371/journal.pone.0116571.

Cappuccino JG, Sherman N. 2002. Microbiology A Laboratory Manual, $6^{\text {th }}$ ed. The Benjamin/ Cummings Publishing Company Inc, New York.

Chen J, Huang PT, Zhang KY, Ding FR. 2012. Isolation of biosurfactant producers, optimization P. T. and properties of biosurfactant produced by Acinetobacter sp. from petroleum-contaminated soil. J Appl Microbiol 112: 660-671.

Cheng M, Zeng G, Huang D, Yang C, Lai C, Zhang C, Liu Y. 2017. Advantages and challenges of Tween 80 surfactant-enhanced technologies for the remediation of soils contaminated with hydrophobic organic compounds. Chem Eng J 314: 98-113.

Choudhuri S. 2014. Bioinformatics for Beginners: Genes, Genomes, Molecular Evolution, Databases and Analytical Tools. Academic Press, United States.

Dominguez JJA, Bacosa HP, Chien M, Inoue C. 2019. Enhanced degradation of polycyclic aromatic hydrocarbons (PAHs) in the rhizosphere of Sudan grass (Sorghum bicolor ssp. drummondii). Chemosphere 234: 789-795.

Dudai N, Tsion I, Shamir SZ, Nitzan N, Chaimovitsh D, Shachter A, Haim A. 2018. Agronomic and economic evaluation of Vetiver grass (Vetiveria zizanioides L.) as means for phytoremediation of diesel polluted soils in Israel. J Environ Manag 211: 247-255 
Farooq A, Shafaghat H, Jae J, Jung S, Park Y. 2019. Enhanced stability of bio-oil and diesel fuel emulsion using Span 80 and Tween 60 emulsifiers. J Environ Manag 231: 694-700.

Hameed M, Ashraf M, Naz N, Al-Qurainy F. 2010. Anatomical adaptations of Cynodondactylon (L.) Pers., from the salt range Pakistan, to salinity stress (i) - root and stem anatomy. Pak J Bot 42 (1): 279-289.

Han Y, Zhang Y, Xu C, Hsu CS. 2018. Molecular characterization of sulfur-containing compounds in petroleum. Fuel 221: 144-158.

Joye S, Kleindienst S, Peña-montenegro TD. 2018. SnapShot: microbial hydrocarbon bioremediation. Cell 172 (6): 1336-1336.

Khan MAI, Biswas B, Smith E, and Arif S. 2018. Ecotoxicology and environmental safety microbial diversity changes with rhizosphere and hydrocarbons in contrasting soils. Ecotox Environ Safe 156: 434 442.

Kiiskila JD, Sarkar D, Panja S, Sahi SV, Datta R. 2019. Remediation of acid mine drainage-impacted water by Vetiver grass (Chrysopogon zizanioides): a multiscale long-term study. Ecol Eng 129: 97-108.

Lagos ML, Maruyama F, Nannipieri P, Mora ML, Ogram A, Jorquera MA. 2015. Current overview on the study of bacteria in the rhizosphere by modern molecular techniques: A mini-review. J Soil Sci Plant Nut 15 (2): 504-523.

Lai C, Huang YC, Wei Y, Chang J. 2009. Biosurfactant-enhanced removal of total petroleum hydrocarbons from contaminated soil. J Hazard Mater 167 (1-3): 609-614.

Leahy JH, Colwell R. 1990. Microbial degradation of hydrocarbons in the environment. Microbiol Rev 54 (3): 305-315.

Lee SH, Kim JH, Chung CW, Kim DY, Rhee YH. 2017. Analysis of medium-chain-length polyhydroxyalkanoate-producing bacteria in activated sludge samples enriched by aerobic periodic feeding. Microb Ecol 75 (3): 720-728.

Maiden MC, Bygraves JA, Feil E, Morelli G, Russell JE, Urwin R. 1998. Multilocus sequence typing: a portable approach to the identification of clones within populations of pathogenic microorganisms. Proc Natl Acad Sci USA 95 (6): 3140-3145.

Maier RM, Pepper IL. 2009. Earth Environments. In: Maier RM, Pepper IL, Gerba CP (eds) Environmental Microbiology (2nd ed.). Academic Press Inc, USA.

McDonald IR, Miguez CB, Rogge G, Bourque D, Wendlandt KD, Groleau D, Murrell JC. 2006. Diversity of soluble methane monooxygenase-containing methanotrophs isolated from polluted environments. FEMS Microbiol Lett 255 (2): 225-232.

Miller GA, Baeckwith R, Fellbaum C, Gross D, Miller K. 1990. Introduction to wordnet: an on-line lexical database. Int J Lexicogr 3: 235-312.

Mousset E, Oturan N, van Hullebusch ED, Guibaud G, Esposito G, Oturan MA. 2014. Influence of solubilizing agents (cyclodextrin or surfactant) on phenanthrene degradation by electro-fenton processstudy of soil washing recycling possibilities and environmental impact. Water Res 48: 306-316.

Nei M. 1987. Molecular Evolutionary Genetics. Columbia University Press, New York

Onyemauche AG, Godson TF, Diselph MB. 2018. Tolerance and bioaccumulation of TPH in Caesalpinia pulcherrima L. and Imperata cylindrica $\mathrm{L}$. of crude oil contaminated soils amended with cow dung. Am J Earth Environ Sci 1 (3): 107-114.

Paul NC, Ji SH, Deng JX, Yu SH. 2013. Assemblages of endophytic bacteria in chili pepper (Capsicum annuum L.) and their antifungal activity against phytopathogens in vitro. Plant Omics 6 (6): 441-448.

Pelczar MJ, Chan ECS. 2010. Microbiology. $5^{\text {th }}$ Edition. Tata McGrawHill Education Pvt. Ltd, New Delhi.

Qian-rui Z, Qi-xingij Z, Li-ping REN, Yong-man ZHU, Shu-lan SUN 2006. Ecological effects of crude oil residues on the functional diversity of soil microorganisms in three weed rhizospheres. J Environ Sci 18 (6): 1101-6.

Rajaei S, Seyedi S, Raiesi F, Shiran B, Raheb J. 2013. Characterization and potentials of indigenous oil-degrading bacteria inhabiting the rhizosphere of wild oat. Iran J Biotechnol 11 (1): 32-40.

Retnaningrum E, Wilopo W. 2018. Production and characterization of biosurfactant produced by Pseudomonas aeruginosa B031 isolated from a hydrocarbon phytoremediation field. Biotropia 25: 130-139.

Ron Z, Rosenberg E. 2014. Enhanced bioremediation of oil spills in the sea. Curr Opin Biotechnol 27C: 191-194.

Rossi-tamisier M, Benamar S, Raoult D. 2015. Cautionary tale of using $16 \mathrm{~S}$ rRNA gene sequence similarity values in identification of human-associated bacterial species. Int J Syst Evol Microbiol 65: 1929-1934

Rousk J, Baath E, Brookes PC, Lauber CL, Lozupone C, Caporaso JG, Knight R, Fierer N. 2010. Soil bacterial and fungal communities across a pH gradient in an arable soil. ISME J 4:1340-1351.

RoyChowdhury A, Sarkar D, Datta R. 2015. Remediation of acid mine drainage-impacted water. Curr Pollut Rep 1 (3): 131-141.

Sambrook J, Fritsch EF, Maniatis T. 1989. Molecular Cloning, A Laboratory Manual, 2nd Edition. Cold Spring Harbor Laboratory, Cold Spring Harbor, New York.

Singh A, Hamme JDV, Ward OP. 2007. Surfactants in microbiology and biotechnology: Part 2. Appl Aspects Biotechnol Adv 25: 99-121.

Singh B, Bhattacharya A, Channashettar VA, Jeyaseelan CP, Gupta S, Sarma PM, Mandal AK, Lal B. 2012. Biodegradation of oil spill by petroleum refineries using consortia of novel bacterial strains. Bull Environ Contam Toxicol 89: 257-262.

Souza EC, Vessoni-Penna TC, Oliveira RPDS. 2014. Biosurfactantenhanced hydrocarbon bioremediation: An overview. Int Biodeterior Biodegrad 89: 88-94.

Srivastava N, Vishwakarma P, Bhardwaj Y, Singh, A, Manjunath K, Dubey SK. 2017. Kinetic and molecular analyses reveal isoprene degradation potential of Methylobacterium sp. Bioresour Technol 242: 87-91.

Stackebrandt E, Goebel BM. 1994. Taxonomic note: a place for DNADNA reassociation and 16S rRNA sequence analysis in the present species definition in bacteriology. Int J Syst Bacteriol 44: 846-849.

Thompson JD, Higgins DG, Gibson TJ. 1994. CLUSTAL W: improving the sensitivity of progressive multiple sequence alignment through sequence weighting, position-specific gap penalties and weight matrix choice. Nucleic Acids Res 22: 4673-4680.

Tian W, Yao J, Liu R, Zhu M, Wang F, Wu X, Liu H. 2016. Effect of natural and synthetic on crude oil biodegrdation by indigenous strains. Ecotoxicol Environ Saf 129: 171-179.

Truu J, Truu M, Espenberg M, Nõlvak H, Juhanson J. 2015. Phytoremediation and plant-assisted bioremediation in soil and treatment wetlands: A review. Open Biotechnol J 9: 85-92.

Turner NR, Renegar DA. 2017. Petroleum hydrocarbon toxicity to corals : A review. Mar Pollut Bull 119: 1-16.

Walker CH. 2006. Principles of Ecotoxicology. CRC, Taylor and Francis, Boca Raton, USA.

Wang X, Jordan IK, Mayer LW. 2015. A Phylogenetic Perspective on Molecular Epidemiology. Molecular Medical Microbiology ThreeVolume Set. Elsevier Ltd, USA.

Vieira PA, Vieira RB, Franca FP, Cardoso VL. 2007. Biodegradation of effluent contaminated with diesel fuel and gasoline. J Hazard Mater 140 (1-2): 52-59.

Zhou JW, Hou B, Liu GY, Jiang H, Sun B, Wang ZN, Shi RF, Xu Y, Wang R, Jia AQ. 2018. Attenuation of Pseudomonas aeruginosa biofilm by hordenine: a combinatorial study with aminoglycoside antibiotics. Appl Microbiol Biotechnol 102 (22): 9745-9758. 